\title{
Waste Characterization of Activation Product Radionuclides in High Level Waste (HLW) Supernate (U)
}

by

C. E. Bess

Westinghouse Savannah River Company

Savannah River Site

Aiken, South Carolina 29808

DOE Contract No. DE-AC09-89SR18035

This paper was prepared in connection with work done under the above contract number with the U.S. Department of Energy. By acceptance of this paper, the publisher and/or recipient acknowledges the U.S. Government's right to retain a nonexclusive, royalty-free license in and to any copyright covering this paper, along with the right to reproduce and to authorize others to reproduce all or part of the copyrighted paper.

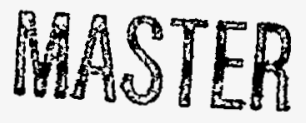




\section{DISCLAIMER}

This report was prepared as an account of work sponsored by an agency of the United States Government. Neither the United States Government nor any agency thereof, nor any of their employees, make any warranty, express or implied, or assumes any legal liability or responsibility for the accuracy, completeness, or usefulness of any information, apparatus, product, or process disclosed, or represents that its use would not infringe privately owned rights. Reference herein to any specific commercial product, process, or service by trade name, trademark, manufacturer, or otherwise does not necessarily constitute or imply its endorsement, recommendation, or favoring by the United States Government or any agency thereof. The views and opinions of authors expressed herein do not necessarily state or reflect those of the United States Government or any agency thereof. 


\section{DISCLAIMER}

Portions of this document may be illegible in electronic image products. Images are produced from the best available original document. 
REVISION: 0

KEYWORDS:

Activation Products

Waste Characterization

RETENTION:

Permanent

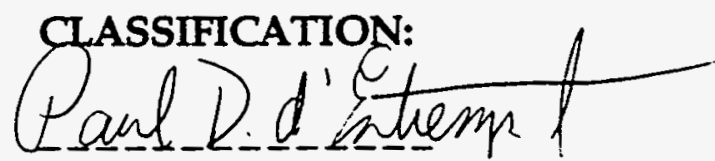
Authorized Derivative

Classifier

\section{Waste Characterization of Activation Product Radionuclides \\ In High Level Waste (HLW) Supernate (U)}

BY

C. E. BESS

Issued: June 30, 1994

CEE. Bess

J. R. Fowler, Technical Reviewer

Mile C Cha O

M.C. Chandler, Manager, HLWE Technology Studies

Mihall Chan Al for

J. E. Marra, Manager, HLWE Support Sulickent tor

T. M. Monahon, Manager, HLWE (Approved)
Date: $6 / 30194$

Date: $2 / 6 / 94$

Date: $6 / 30 / 94$

Date:--7/6/94

Date:_I/14/94

Date: $7 / 19 / 94$ 


\section{INTRODUCTION}

An evaluation has been made of the radionuclides produced as products of reactor neutron activation as they exist in High Level Waste (HLW) and their potential to contaminate and impact Low Level Waste (LLW). Process knowledge was used to define the source terms of tritium, carbon, nickel, and cobalt activation products in HLW in an effort to help characterize these radionuclides in HLW supernate in support of LLW Certification. This report uses waste tank sample data and materials inventory data to determine the potential for waste packages, contaminated with tank supernate, to exceed the E-Area Vault (EAV) Package Acceptance Criteria (PAC).

\section{SUMMARY}

Process knowledge has been used to evaluate the impact of ${ }^{3} \mathrm{H},{ }^{14} \mathrm{C},{ }^{59} \mathrm{Ni}$, and ${ }^{60} \mathrm{Co}$ radionuclides within Waste Management Facilities such that the requirements of the waste acceptance criteria for the storage and disposal of low-level waste in the E Area vaults (EAV) are not compromised. It is very unlikely that waste packages contaminated with waste tank supernate will exceed the Low Activity Waste Vault (LAWV) PAC for the activation products of ${ }^{3 \mathrm{H}},{ }^{14} \mathrm{C},{ }^{59} \mathrm{Ni}$, or ${ }^{60} \mathrm{Co}$. Tritium, ${ }^{14} \mathrm{C}, 59 \mathrm{Ni}$ and ${ }^{60} \mathrm{Co}$ are shown to have negligible, if any, impact to the LAWV PAC from waste generated in the tank farms. The volume(s) of supernate required to reach the PAC in the evaluation of these radionuclides is in excess of the B-25 waste package volume. Concentrations of these radionuclides in supernate should be considered less than the Minimum Reportable Quantity and do not require manifesting.

\section{DISCUSSION}

Activation products are radionuclides produced in the reactor as a result of neutron bombardment of materials in the fuel and target tubes. Four of the radionuclides of concern for LLW Certification are activation products; Tritium $\left({ }^{3} \mathrm{H}\right)$, Carbon-14 $\left({ }^{14} \mathrm{C}\right)$, Nickel-59 $(59 \mathrm{Ni})$, and Cobalt-60 $(60 \mathrm{Co})$. These radionuclides have been transferred to HLW from SRS production processes. The production and origin of these nuclides in HLW based on process knowledge is discussed below.

\section{Tritium}

Tritium that reaches the waste tanks originates as either a fission product or from neutron capture by heavy water moderator (subsequently removed 
from the surface of irradiated Li-Al Control Rods/Target Tube jackets at the Receiving Basin for Offsite Fuels (RBOF)). The amount handled in the HLW system in a given year is a function of irradiation and process schedules and the fraction removed by canyon evaporators before the waste solutions reach the tanks.

Approximately $8000 \mathrm{Ci} / \mathrm{yr}$. of tritium, determined by a balance across the waste management system, is released to the environment from waste handling operations. Most of that total is released to the atmosphere in the waste ventilation purge used to prevent the accumulation of hydrogen in a waste tank. 2

Tritium samples have been taken from waste storage tanks for analysis. However, a laboratory sample program is pending and this data is not available to evaluate tritium as a supernate waste contaminant. Sample results, when the analyses are completed, will be tracked in the HLWE sample data base.

Tritium generated within reactor fuel or targets as a result of fission yield has a minor impact on HLW. Based on a fission yield analysis and a 5 year decay, the amount of tritium is only $2.85 \mathrm{Ci}$ per assembly. Cs-137 on the other hand has a fission yield of $2920 \mathrm{Ci}$ per assembly. Based on these projections, tritium enters HLW at a concentration 1000 times less than the cesium Ci concentration. This results in a $13000 x$ difference between cesium and tritium relative to the LAWV PAC. 12 Thus, the concentration of fission product tritium is low relative to its $\mathrm{PAC}$, and, since tritium cannot be concentrated in HLW, there is no potential for fission yield tritium impacting LLW.

No inventory of tritium transfers from separations was captured in historical records of waste transfers. However, Tank $17 \mathrm{~F}$ received a large volume of tritiated waste direct from reactor facilities which bounds the tritium concentration of waste management facilities.

Tank $17 \mathrm{~F}$ contains 6000 curies in 274,000 gallons $\left(162,000^{*}\right.$ gallons stored in the tank per historical records plus 112,000 gallons received from K-Reactor). 5,6 , 7 Ignoring dilution by other liquid which could be stored in Tank 17F, the concentration of tritium in the tank has been calculated to be $0.02 \mathrm{Ci} / \mathrm{gal}$. Historical records revealed that the tritium concentration upper bound for waste management handling facilities prior to the Tank $17 \mathrm{~F}$ receipt of tritium from K-Reactor was 5.0E-03 Ci/gal. ${ }^{2}$

* From WSRC-RP-91-78-12B, Waste Management Monthly Data Record 1991 (U) 
The tritium concentration upper bound for waste management handling facilities $(0.02 \mathrm{Ci} / \mathrm{gal})$ is a result of the Tank $17 \mathrm{~F}$ receipt of tritiated water from $\mathrm{K}$-Reactor. From this assumption, the maximum number of gallons of liquid from Tank 17F that can be placed in a B-25 waste container such that the Low Activity Waste Vault (LAWV) PAC is not exceeded can be calculated (see calculation below).

- LAWV PAC for tritium is 1.0E01 Ci/package 8

$$
\begin{aligned}
\text { \# gallons } / \text { package } & =(1.0 \mathrm{E} 01 \mathrm{Ci} / \text { package }) /(0.02 \mathrm{Ci} / \text { gal }) \\
& =500 \text { gallons } / \text { package }
\end{aligned}
$$

Thus, it is highly unlikely that the tritium PAC will be exceeded in any waste package.

Tank $17 \mathrm{~F}$ is known to be the bounding condition due to sampling of tank exhaust and bioassay sampling due to exposure concerns for tank farm personnel. Due to the continuous air purge and the vapor pressure of the waste in Tank 17F, a portion of the water vapor evaporates. Tritium is expected to exhibit physical properties similar to light water, so that evaporation of the tank contents would also introduce some tritium into the tank exhaust. Because of the proximity of the 1F Control Room to the Tank $17 \mathrm{~F}$ exhaust stack, a study was undertaken to assure that the tritium levels in the air were below levels requiring respiratory protection. Health Protection (HIP) requirements specify that the tritium concentration not exceed 1 Derived Air Concentration unit (DAC), where a DAC is defined as $2.0 \mathrm{E}-05 \mu \mathrm{Ci} / \mathrm{cC}$. Three mathematical models were combined to estimate the tritium concentration in the air downstream from Tank 17F. The concentration of tritium was predicted to be $1.6 \mathrm{E}-05 \mu \mathrm{Ci} / \mathrm{cc}$. The concentration of tritium in air (sampled) around Tank 17 was found to be $1.2 \mathrm{E}-05 \mu \mathrm{Ci} / \mathrm{cc}$ which showed good comparison to the predicted concentration. Sample data outside of the $1 F$ Control Room reflected that under normal conditions, the concentrations would be 2-3 orders of magnitude less than the HP limit. 7

Since tritium will always be released with water vapor, there is no credible mechanism in the Tank Farms to concentrate it further. It can therefore be anticipated that the tank concentrations of tritium will continue to diminish further, due to additional dilution and radioactive decay. Since a concentration mechanism for tritium in HLW does not exist, tritium in HLW cannot impact the EAV waste package acceptance criteria. 


\section{Carbon}

The most useful way to specify the ${ }^{14} \mathrm{C}$ production rate is as ${ }^{14} \mathrm{C} \mathrm{Ci} / \mathrm{KMWD}$ (Thousand Megawatt Days). This is a charge dependent quantity, with high production rates at higher thermal neutron fluxes. It ranges from a low value of $0.064 \mathrm{Ci} / \mathrm{KMWD}$ for Mark 16-31 operation to a high value of 1.11 $\mathrm{Ci} / \mathrm{KMWD}$ for the high flux charges operated in the mid 60's. ${ }^{1}$

Carbon-14 can be produced by the reactions, ${ }^{14} \mathrm{~N}(n, p){ }^{14} \mathrm{C},{ }^{17} \mathrm{O}(n, \alpha){ }^{14} \mathrm{C}$, and ${ }^{13} \mathrm{C}(n, \gamma){ }^{14} \mathrm{C}$. At SRS, almost all of the ${ }^{14} \mathrm{C}$ is produced from the ${ }^{17} \mathrm{O}(\mathrm{n}, \alpha){ }^{14} \mathrm{C}$ in reactor moderator. Oxygen-17 is a constituent of the moderator, comprising $0.038 \%$ of the total oxygen. Carbon-14 is also produced by the other two reactions, but the contributions to SRS production of $14 \mathrm{C}$ are negligible because nitrogen and carbon are available in reactor processes only as impurities in trace amounts.

Carbon-14 accumulation in F-Area cladding waste (from caustic dissolution) is the only source from neutron activation of nitrogen impurities in aluminum cladding that can be measured in supernate samples. The average concentration of ${ }^{14} \mathrm{C}$ measured from coating waste from F-Area is captured in Table 1.4

Sample results are the only available source of ${ }^{14} \mathrm{C}$ representative of the waste stream from SRS reactor production. 3,4 No inventory of carbon isotopics has been tracked as a result of waste transfers from separations. For this analysis, the best source of available data has been the concentration of ${ }^{14} \mathrm{C}$ in waste tanks which has been extracted from sample results. 3,4

The concentration of ${ }^{14} \mathrm{C}$ from Tank 50 sample analysis was found to be $5.36 \mathrm{E}$ $08 \mathrm{Ci} / g a l .3$ The average concentration from samples of F-Area coating waste was measured as $9.46 \mathrm{E}-06 \mathrm{Ci} / \mathrm{gal} .4$

A minimum of over 349 gallons/package of ${ }^{14} \mathrm{C}$ contaminated supernate would have to be attained to compromise the EAV Waste Package Administrative Control Limit for ${ }^{14} \mathrm{C}$. Thus, it is highly unlikely that ${ }^{14} \mathrm{C}$ would exceed PAC in any waste package. 
Table 1

Volume of Supernate to Reach LAWV PAC

\begin{tabular}{|c|c|c|c|c|}
\hline $\begin{array}{l}\text { TK } 50 \text { C-14 } \\
\text { Conc. } \\
\text { (nCi/aram) }\end{array}$ & $\begin{array}{l}\text { Sample } \\
\text { Density } \\
\text { (ma/l) }\end{array}$ & $\begin{array}{c}\text { TK } 50 \text { C-14 } \\
\text { Conc. } \\
\text { (Ci/gal) }\end{array}$ & C-14 PAC & $\begin{array}{l}\text { Vol. of Supernate } \\
\text { for PAC (gal) }\end{array}$ \\
\hline $1.18 \mathrm{E}-02$ & 1.2 & $5.36 \mathrm{E}-08$ & $3.30 E-03$ & $6.16 \mathrm{E}+04$ \\
\hline $\begin{array}{l}\text { C-14 Conc. } \\
\text { Coating Waste } \\
(n \mathrm{Ci} / \mathrm{ml})\end{array}$ & & $\begin{array}{c}\text { C-14 Conc. } \\
\text { Coating Waste } \\
(\mathrm{Ci} / \mathrm{ga})\end{array}$ & & $\begin{array}{l}\text { Vol. of Supernate } \\
\text { for PAC (gal) }\end{array}$ \\
\hline 2.5 & & $9.46 E-06$ & $3.30 E-03$ & $3.49 E+02$ \\
\hline
\end{tabular}

\section{Nickel}

Nickel-59 is a neutron activation product of $58 \mathrm{Ni}$ resulting from the $58 \mathrm{Ni}(\mathrm{n} \gamma$ ) reaction during irradiation of reactor assemblies. The natural abundance of $58 \mathrm{Ni}$ is $68.3 \%$. Nickel is present in SRS assemblies as an impurity in aluminum cladding and as a coating on uranium slugs. It is present in nonSRS reactor fuels (RBOF fuels) as a component of stainless steel cladding.

Nickel in high-level waste comes from nickel in the targets (bonding agent between $\mathrm{U}$ core and $\mathrm{Al}$ coating). A history of $\mathrm{Ni}(\mathrm{OH})_{2}$ stored in waste tanks has been captured in WSRC-TR-94-0191, "Estimated Sludge Inventory For Individual Tanks." 10

${ }^{59} \mathrm{Ni}$ abundance in 15-year waste was determined to be $0.239 \% .11$ Production

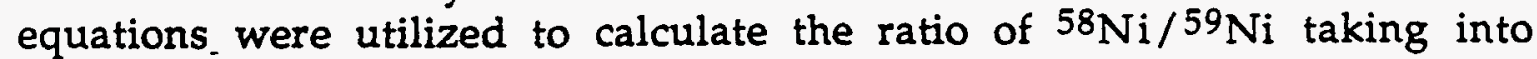
consideration the various fuel and target components which were irradiated in SRS Reactors (i.e., Mk 16B, Mk 31A, Mk 31B, Mk 22, and MK 53A). The ratios per assembly type were weighted by the volume proportions of SRS wastes to determine ratios in average SRS waste.

$\mathrm{Ni}(\mathrm{OH})_{2}$ inventory data was used to determine the amount of $\mathrm{Ni}(63.32 \%)$. The ${ }^{59} \mathrm{Ni}$ content was equated by multiplying the mass of $\mathrm{Ni}$ by the percent abundance in 15 -year waste (i.e., $0.239 \%)$. The specific activity of ${ }^{59} \mathrm{Ni}(8.080$ 
E-02 Ci/g) was used to convert the amount of ${ }^{59} \mathrm{Ni}$ to curies. The concentration of $59 \mathrm{Ni}$ per waste tank was then computed by dividing the number of curies of $59 \mathrm{Ni}$ by the total volume (gallons) of waste received into the tanks (captured from historical records 10). For the purposes of this calculation, the nickel was conservatively assumed to be soluble.

Comparing the concentration of ${ }^{59} \mathrm{Ni}$ per waste tank to the LAWV PAC allowed the volume of supernate per package to be calculated (Table 2). The minimum volume required to reach PAC is 674 gallons. Thus, it is highly unlikely that the PAC for nickel would be exceeded in any waste package.

Table 2

Volume of Supernate to Reach LAWV PAC

\begin{tabular}{|c|c|c|c|c|c|c|c|c|}
\hline Tank & $\begin{array}{c}\text { Total } \\
\text { Gal. }\end{array}$ & $\begin{array}{c}\mathrm{NI}(\mathrm{OH}) \\
2\end{array}$ & NI & NI.59 & NI.59 & $N 1-59$ & N1.59 & $\begin{array}{c}\text { Vol. of } \\
\text { Supernate }\end{array}$ \\
\hline & $\begin{array}{c}\text { Rocolve } \\
d\end{array}$ & $(\mathrm{Kg})$ & $(\mathrm{Kg})$ & $(\mathrm{Kg})$ & $(\mathrm{CI})$ & $(\mathrm{Cl} / \mathrm{ga})$ & PAC & PAC (gal) \\
\hline & & & & & & & & \\
\hline 1 & $1.88 E+06$ & 1194 & 756 & 181 & $1.46 E+04$ & 7.78E-06 & $6.30 E-02$ & $8.10 E+03$ \\
\hline 2 & $7.49 E+05$ & 105 & 66 & 16 & $1.28 E+03$ & 1.72E-06 & $6.30 E-02$ & $3.67 E+04$ \\
\hline 3 & $8.10 E+05$ & 204 & 129 & 31 & $2.49 E+03$ & $3.08 E-06$ & $6.30 \mathrm{E}-02$ & $2.05 E+04$ \\
\hline 4 & $1.43 E+06$ & 10898 & 6901 & 1649 & $1.33 E+05$ & $9.35 E-05$ & $6.30 \mathrm{E}-02$ & $6.74 E+02$ \\
\hline 5 & $1.73 E+06$ & 5483 & 3472 & 830 & $6.70 E+04$ & $3.87 E-05$ & $6.30 \mathrm{E}-02$ & $1.63 E+03$ \\
\hline 6 & $1.22 E+06$ & 7140 & 4521 & 1081 & $8.73 E+04$ & $7.18 E-05$ & 6.30E-02 & $8.78 E+02$ \\
\hline 7 & $9.99 E+06$ & 7286 & 4613 & 1103 & $8.91 E+04$ & $8.92 E-06$ & $6.30 \mathrm{E}-02$ & $7.07 E+03$ \\
\hline 8 & $5.35 E+06$ & 6852 & 4339 & 1037 & $8.38 E+04$ & 1.57E-05 & $6.30 E-02$ & $4.02 E+03$ \\
\hline 9 & $8.08 E+05$ & 100 & 63 & 15 & $1.22 E+03$ & $1.51 \mathrm{E}-06$ & $6.30 \mathrm{E}-02$ & $4.16 E+04$ \\
\hline 10 & $8.41 E+05$ & 22 & 14 & 3 & $2.69 \mathrm{E}+02$ & 3.20E-07 & $6.30 \mathrm{E}-02$ & $1.97 E+05$ \\
\hline 11 & $4.83 E+06$ & 476 & 301 & 72 & $5.82 E+03$ & $1.20 \mathrm{E}-06$ & $6.30 \mathrm{E}-02$ & $5.23 E+04$ \\
\hline 12 & $3.56 E+06$ & 4028 & 2551 & 610 & $4.93 E+04$ & 1.38E-05 & $6.30 \mathrm{E}-02$ & $4.55 E+03$ \\
\hline 13 & $7.53 E+06$ & 4572 & 2895 & 692 & $5.59 E+04$ & 7.42E.06 & $6.30 \mathrm{E}-02$ & $8.49 E+03$ \\
\hline 14 & $7.87 E+05$ & 256 & 162 & 39 & $3.13 E+03$ & $3.98 E-06$ & $6.30 E-02$ & $1.58 E+04$ \\
\hline 15 & $3.79 E+06$ & 26 & 16 & 4 & $3.18 E+02$ & $8.40 E-08$ & $6.30 \mathrm{E}-02$ & $7.50 \mathrm{E}+05$ \\
\hline 32 & $3.15 E+06$ & 1394 & 883 & 211 & $1.70 E+04$ & 5.42E.06 & $6.30 \mathrm{E}-02$ & $1.16 E+04$ \\
\hline 33 & $1.31 E+06$ & 6628 & 4197 & 1003 & $8.10 E+04$ & $6.18 E-05$ & $6.30 E-02$ & $1.02 E+03$ \\
\hline 34 & $2.00 E+06$ & 10345 & 6550 & 1566 & $1.26 E+05$ & $6.31 E-05$ & $6.30 E-02$ & $9.98 \mathrm{E}+02$ \\
\hline 35 & $2.65 E+06$ & 2217 & 1404 & 336 & $2.71 E+04$ & $1.02 E \cdot 05$ & $6.30 E-02$ & $6.16 E+03$ \\
\hline 42 & $1.13 E+05$ & 12 & 8 & 2 & $1.47 E+02$ & 1.30E-06 & $6.30 \mathrm{E}-02$ & $4.85 E+04$ \\
\hline
\end{tabular}




\section{Cobalt}

Cobalt is a minor impurity in structural materials. Cobalt- 60 is produced by neutron activation of ${ }^{59} \mathrm{Co}$ and ${ }^{60} \mathrm{Ni}$. There is no credible mechanism for production of significant quantities of $60 \mathrm{Co}$ in canyon feed. Neutron activation of naturally occurring ${ }^{60} \mathrm{Ni}$ is assumed to be the major source of $60 \mathrm{Co}$ in the waste ( $n, \mathrm{p}$ reaction), due to the Ni cladding on targets.

The concentration of ${ }^{60} \mathrm{Co}$ in a sludge supernate mixture of 15 year soluble waste was estimated from a previous evaluation to be $5.1 \mathrm{E}-03 \mathrm{Ci} / \mathrm{gal} .2$

No inventory of cobalt isotopics has been tracked as a result of waste transfers from separations. For this analysis, the best source of available data has been the concentration of ${ }^{60} \mathrm{Co}$ in waste tanks (captured in the HLWE data base of tank sample results).

The concentration of ${ }^{60} \mathrm{Co}$ in waste tanks has been extracted from the HLWE data base of tank sample results and captured in Table 4 for comparison to the LAWV PAC. The average concentration of ${ }^{60} \mathrm{Co}$ from available tank samples was equated to be $2.49 \mathrm{E}-02 \mathrm{Ci} / \mathrm{gal}$. The maximum concentration from any waste tank was measured as $1.70 \mathrm{E}-01 \mathrm{Ci} / \mathrm{gal}$.

Unlike the other activation products, the concentration of ${ }^{60} \mathrm{Co}$ can be measured in $\mathrm{HLW}$ because ${ }^{60} \mathrm{Co}$ emits a strong gamma that is readily detected, whereas the other radionuclides are beta emitters. 
Table 3

Volume of Supernate to Reach LAWV PAC

\begin{tabular}{|c|c|c|c|}
\hline TANK & Co-60 (Cl/gal) & C0.60 PAC & Vol. of Supernate for \\
\hline & & & Co-60 PAC (gal) \\
\hline & & & \\
\hline 1 & 1.70E-01 & $2.30 \mathrm{E}+01$ & $1.35 \mathrm{E}+02$ \\
\hline 2 & $1.26 E-01$ & $2.30 E+01$ & $1.83 E+02$ \\
\hline 3 & $1.26 \mathrm{E}-01$ & $2.30 \mathrm{E}+01$ & $1.83 E+02$ \\
\hline 4 & $9.89 E-02$ & $2.30 \mathrm{E}+01$ & $2.33 E+02$ \\
\hline 9 & $6.82 E-06$ & $2.30 E+01$ & $3.37 E+06$ \\
\hline 10 & $1.19 \mathrm{E}-05$ & $2.30 E+01$ & $1.93 E+06$ \\
\hline 13 & 3.41E-06 & $2.30 E+01$ & $6.74 E+06$ \\
\hline 14 & 5.11E-06 & $2.30 E+01$ & $4.50 E+06$ \\
\hline 15 & $6.82 E-06$ & $2.30 E+01$ & $3.37 E+06$ \\
\hline 21 & $1.21 E .03$ & $2.30 E+01$ & $1.90 \mathrm{E}+04$ \\
\hline 25 & 2.90E-06 & $2.30 E+01$ & $7.93 E+06$ \\
\hline 26 & 1.19E-07 & $2.30 E+01$ & $1.93 E+08$ \\
\hline 27 & 3.75E-06 & $2.30 E+01$ & $6.13 E+06$ \\
\hline 28 & $1.19 E-07$ & $2.30 E+01$ & $1.93 E+08$ \\
\hline 29 & 8.01E-06 & $2.30 E+01$ & $2.87 E+06$ \\
\hline 30 & 5.11E-07 & $2.30 E+01$ & $4.50 E+07$ \\
\hline 32 & $1.70 E-07$ & $2.30 E+01$ & $1.35 E+08$ \\
\hline 33 & 1.88E.06 & $2.30 \mathrm{E}+01$ & $1.22 E+07$ \\
\hline 34 & 2.05E-06 & $2.30 E+01$ & $1.12 E+07$ \\
\hline 38 & $1.70 \mathrm{E}-07$ & $2.30 \mathrm{E}+01$ & $1.35 E+08$ \\
\hline 50 & $2.86 E-07$ & $2.30 E+01$ & $8.04 E+07$ \\
\hline
\end{tabular}

Thus, it is highly unlikely that ${ }^{60} \mathrm{Co}$ would exceed its PAC in any waste package.

\section{REEERENCES}

1. DPST-88-578, "Carbon-14 Production In Moderator of SRP Charges", June 1988.

2. DPSTSA-200-10 SUP-18, "Safety Analysis - 200 Area Liquid Radioactive Waste Handling Facilities". 
3. J. E. Batton to R. M. Sprague, OPS-DPF-890036, "Tank 50 Sample Results"(U).

4. J.R.Fowler and C.J.Coleman, to R.B.Ferguson and C.E.Coffey, DPST-832001, "Carbon-14 In Sludge", December 28, 1983.

5. G. K. Georgeton to B. L. Lewis, WER-WMT-920022,"Tritium Calculations for Tank 17 Following K-Area Water Addition"(U).

6. G. K. Georgeton to B. L. Lewis, WER-WMT-920142,"Updated Tritium and Chemistry Calculations for Tank 17 Following K-Area Water Addition"(U).

7. G. K. Georgeton to B. L. Lewis, WER-WMT-920752, "Reevaluation of the Need for Dilution to Reduce the Tritium Concentration in Tank 17"(U).

8. Manual 1S, WAC 3.10, "Savannah River Site Waste Acceptance Criteria Manual"(U).

9. WSRC-TR-93-135, "Separations Waste Sludge Spreadsheet"(U), July 28, 1993.

10. WSRC-TR-94-0191, "Estimated Sludge Inventory For Individual Tanks" (U), May 4, 1994.

11. J. R. Chandler to M. R. Buckner, "59Ni, $63 \mathrm{Ni}$, and ${ }^{94} \mathrm{Nb}$ In DWPF Saltcrete", DPST-82-236.

12. DPSTD-80-39, "Preliminary Technical Data Summary-Defense Waste Facility-Stage 2, " December 1980. 